\title{
Repository Portofolio TA Mahasiswa Teknik Informatika UAI
}

\author{
Riri Safitri ${ }^{1}$, Muhammad Surya Gemilang ${ }^{2}$, Denny Hermawan ${ }^{3}$ \\ 1,2,3 Program Studi Teknik Informatika, Fakultas Sains dan Teknologi, Universitas Al Azhar \\ Indonesia, Jalan Sisingamangaraja, Kompleks Masjid Agung Al Azhar, Jakarta Selatan 12110 \\ Penulis untuk Korespondensi/ Email: riri@uai.ac.id
}

\begin{abstract}
Abstrak - Tugas Akhir (TA) merupakan tahapan terakhir yang harus dilalui oleh setiap mahasiswa untuk menjadi sarjana. TA merupakan suatu bentuk implementasi mahasiswa terhadap ilmu-ilmu yang telah dipelajari selama perkuliahan untuk menyelesaikan suatu permasalahan. Di Universitas Al Azhar Indonesia, khususnya prodi Teknik Informatika, buku laporan TA yang telah dikumpulkan disimpan di Sekretariat Fakultas dan perpustakaan Universitas, sedangkan CD laporan TA disimpan di laboratorium. CD yang disimpan di laboratorium semakin hari semakin banyak dan tidak dimanfaatkan dengan baik. Mahasiswa yang membutuhkan informasi terkait dengan penelitian yang akan dilakukan akan datang ke perpustakaan dan membaca buku laporan TA yang tersimpan. Mahasiswa juga dapat melihat abstrak dan file TA di website perpustakaan, tapi terbatas untuk laporan TA dengan nilai A. Untuk memberikan kemudahan dalam menyimpan dan mendapatkan informasi mengenai TA, maka dibuatlah sebuah repository portofolio TA mahasiswa. Melalui repository ini mahasiswa dapat melihat laporan TA dari seluruh lulusan Teknik Informatika UAI berupa poster dan screen shoot aplikasi atau hasil penelitian yang telah dilakukan. Dengan adanya repository ini, membantu prodi Teknik Informatika dalam menyimpan data-data mengenai laporan TA mahasiswa dengan baik dan terawat. Repository ini juga memberikan kemudahan kepada mahasiswa untuk mendapatkan referensi penelitian yang telah dilakukan sebelumnya dari banyak laporan TA melalui satu aplikasi.
\end{abstract}

Kata Kunci - Repositori, Portofolio, TA, Perguruan Tinggi, Web Based Application.

Abstract - Final Project is the last stage that must be passed by every student to become a scholar. Final project is a form of student implementation of the sciences that have been studied during the lecture to solve a problem. At the University of Al Azhar Indonesia, especially Informatics Engineering Department, the book of collected final project reports is stored in the Faculty and University Library Secretariat, while the final project report CD is stored in the laboratory. CD stored in the laboratory are getting more and more and are not being utilized properly. Students who need information related to the research to be conducted will come to the library and read the book of the stored final project reports. Students can also view abstracts and final project files on library websites, but are limited to final project reports with a value. To provide ease in storing and getting information about final project, then made a repository of final project portfolio of students. Through this repository, students can view final project reports from all UAI Informatics Engineering graduates in the form of poster and screen shoot application or research result that has been done. This repository also makes it easy for students to get research references that have been done before from many final project reports through one application.

Keyword-Repository, Portofolio, Final Project, University, Web Based Application. 


\section{PENDAHULUAN}

$\mathrm{R}$ epository institusi merupakan wadah untuk mengelola dan melestarikan aset intelektual institusi. Tidak hanya sekedar mengumpulkan konten, proses membangun repository institusi memerlukan persiapan serius mengenai masalah sarana dan sumber daya manusia. Pembangunan dan pengelolaan ini juga harus dapat dukungan dari pada stakeholder di lingkungan institusi melalui penetapan kebijakan dan peraturan.

Skripsi merupakan TA mahasiswa S1 yang bersifat mandiri dan wajib untuk mendapatkan gelar sarjana. Seorang mahasiswa yang akan menulis TA harus mencari topik penelitian terlebih dahulu untuk menentukan fokus penelitiannya. Ada banyak cara yang dilakukan mahasiswa dalam usaha pencarian topik TA, seperti membaca jurnal penelitian dalam e-journal, mengikuti penelitian yang dilakukan dosen, membaca kumpulan TA yang pernah dibuat, melakukan observasi masalah yang sering timbul di bidangnya dan sebagainya.

Banyak cara mendapatkan topik TA, akan tetapi mencari topik TA bukanlah hal yang mudah, hal ini terbukti dengan banyaknya mahasiswa yang kesulitan untuk memulai mengerjakan TA karena belum mendapatkan topik yang sesuai.

Disamping itu, laporan TA yang dikumpulkan mahasiswa dalam bentuk buku dan CD disimpan di perpustakaan dan laboratorium prodi. Perpustakaan sebagai sumber ilmu merupakan suatu bagian penting yang membutuhkan sistem informasi yang kuat [1]. Hanya saja saat ini laporan TA yang dapat diakses melalui website perpustakaan hanya menampilkan laporan TA dengan nilai A. Sedangkan, CD laporan TA yang dikumpulkan pada prodi semakin hari semakin banyak sehingga membutuhkan waktu yang lama untuk mencari laporan TA yang diinginkan.

Teknologi informasi mempunyai peranan yang sangat diperlukan baik itu pada sebuah sistem informasi, sistem informasi Perguruan tinggi maupun perpustakaan [2]. Saat ini telah banyak universitas ternama yang memiliki repository TA berbasis web yang dapat dikunjungi oleh pihak di luar universitas.
Layanan ini dapat dimanfaatkan oleh mahasiswa untuk mendapatkan ide topik TA.

Untuk itu guna meningkatkan mutu agar lebih baik dan memudahkan dalam mencari data laporan TA, dibangunlah suatu repository portofolio TA berbasis website yang berisi kumpulan TA lulusan prodi Teknik Informatika UAI.

Pembuatan repository portofolio ini menggunakan Wordpress sebagai domain dasar untuk mengakses melalui internet. Diharapkan dengan adanya repository ini dapat membantu prodi Teknik Informatika dalam mengelola data laporan TA dan juga memberikan kemudahan kepada mahasiswa dalam mencari informasi dan referensi TA yang dibutuhkan.

\section{KERANGKA TEORI}

\section{Repository}

Secara sederhana arti dari repositori adalah tempat penyimpanan. Dalam konteks kepustakawanan repositori adalah suatu tempat dimana dokumen, informasi atau data disimpan, dipelihara dan didigunakan. Kadang-kadang istilah repository dipakai untuk menyatakan hal yang sama. Sebuah repositori berisi mekanisme untuk mengimpor, mengidentifikasi, menyimpan, melestarikan, memulihkan dan mengekspor sekumpulan benda digital, biasanya dari portal web [3].

Dari definisi Reizt di atas, terlihat bahwa dokumen yang dikelola dalam repositori lebih khusus dari pada yang dikelola di perpustakaan. Penyelenggara repositori lebih mengkhususkan diri untuk mengelola dokumen yang belum diterbitkan oleh perusahaan penerbitan atau penerbitan komersial. Dokumen yang dikelola oleh penyelenggara repositori sering juga dinamai dengan sebutan literatur kelabu (gray literature) yang dapat berupa dokumen yang khas, buku- buku yang jarang didapatkan di pasar buku, dan juga dokumen yang dihasilkan oleh instansi atau lembaga pemerintah dan sebagainya, sehingga ada yang menyebutnya local contents.

Berbagai sumberdaya informasi berbasis kertas (paperbased), yang selama ini 
merupakan primadona perpustakaan tradisional, sekarang telah banyak tersedia dalam format digital.

\section{Portofolio}

Portofolio secara etimologi berasal dari dua kata, yaitu port (singkatan dari report) yang berarti laporan dan folio yang berarti penuh atau lengkap.

Portofolio merupakan suatu wadah yang berisi sejumlah bukti yang dikumpulkan untuk tujuan tertentu [4]. Dalam referensi lain dinyatakan bahwa Portofolio merupakan kumpulan pekerjaan siswa yang menunjukkan usaha, perkembangan dan kecakapannya dalam suatu bidang atau lebih [5].

Seiring dengan berkembangnya teknologi informasi, berkembanglah portofoliio elektronik, yang lebih dikenal dengan istilah e-portofolio. Elektronik portofolio merupakan kumpulan portofolio yang disusun secara online oleh pengguna, biasanya berbasis web based. Inputan dari e-Portfolio tersebut dapat mencakup teks file elektronik, gambar, multimedia, blog entries, dan hyperlink. Secara umum e-Portfolio mendukung pengembangan dan kemajuan dalam bidang teknologi. Sebagai contoh dalam bidang akademi, hampir setiap kampus menggunakan $e$ Portfolio untuk menyimpan hasil karya dan data - data baik dari dosen dan mahasiswa yang dapat juga berfungsi sebagai pembelajaran satu sama lain

Dilihat dari aspek manfaat, ada 4 hal yang menjadi perhatian utama bagi eksistensi institutional repository sebuah perguruan tinggi, diantaranya sebagai berikut:

1. Untuk mengumpulkan konten dalam satu lokasi sehingga mudah untuk ditemukan kembali

2. Untuk menyimpan dan melestarikan aset intelektual sepanjang waktu.

3. Untuk menyediakan akses terbuka terhadap karya intelektual institusi kepada khalayak umum.

4. Untuk menciptakan visibilitas global bagi hasil karya ilmiah institusi.

\section{METODE PENELITIAN}

Repository Portofolio TA yang dibuat, dirancang dalam Web Based Application. Penelitian ini diawali dengan melakukan analisa kebutuhan, yaitu dengan mengumpulkan informasi mengenai kebutuhan sistem, yang didapatkan dengan wawancara pada Prodi Teknik Informatika.

Setelah mendapatkan informasi kebutuhan sistem, penelitian dilanjutkan dengan perancangan sistem, dengan membuat desain sistem dan berupa database dan user interface sistem. Penelitian dilanjutkan dengan implementasi sistem, dengan pemilihan tools yang dapat digunakan untuk melakukan perancangan dan diakhiri dengan testing atau pengujian. Metode penelitian dapat dilihat pada Gambar 1.

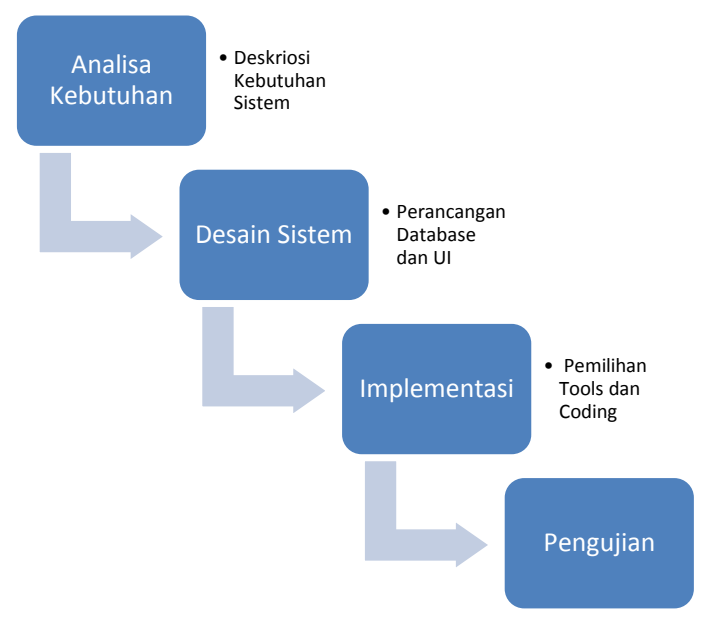

Gambar 1. Metode Penelitian

Berdasarkan hasil wawancara dengan Prodi Teknik Informatika, didapatkan deskripsi kebutuhan sistem sebagai berikut:

1. Sistem diharapkan dapat menyimpan file TA mahasiswa.

2. Sistem diharapkan dapat menyimpan poster TA mahasiswa

3. Sistem diharapkan dapat menampilkan halaman abstrak, yang berisi judul, nama penulis dan nama pembimbing.

4. Sistem diharapkan dapat menampilkan file TA mahasiswa dalam format pdf.

5. Sistem diharapkan dapat memberikan akses kepada user untuk melakukan pencarian TA berdasarkan kategori tahun kelulusan dan nama penulis. 
Berdasarkan hasil analisis kebutuhan sistem, dilakukan perancangan sistem menggunakan Use Case Diagram. Use case diagram sistem terlihat pada Gambar 2.

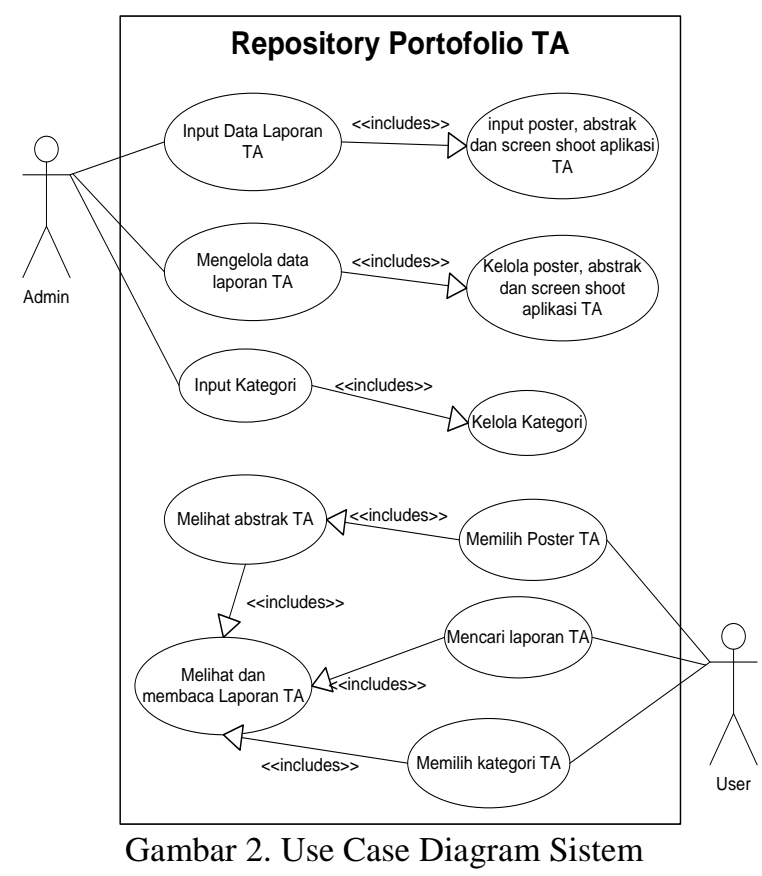

Pada use case diagram terlihat bahwa terdapat dua aktor pada sistem yang dibuat, yaitu admin dan user. Admin adalah staf laboratorium yang akan bertugas melakukan input dan kelola data laporan TA kedalam sistem repository. User adalah mahasiswa atau dosen yang berinteraksi dengan sistem untuk mencari dan membaca data laporan TA yang terdapat didalam sistem.

Setelah melakukan tahap desain, dilanjutkan dengan implementasi sistem yang dilakukan dengan menggunakan PHP dan My SQL. Dalam proses implementasi sistem dibutuhkan beberapa tools untuk membangun sistem repository diantaranya XAMPP, Apache, Wordpress, Plugin Simplest Gallery dan Pdf Light Viewer Plugin.

WordPress merupkan aplikasi CMS terbuka (open source) yang memberikan kebebasana pada pengembang untuk membangun web dan blog yang dinamis [6]. Pemilihan Wordpress sebagai web engine dalam pembuatan sistem ini, dikarenakan Wordpress merupakan salah satu web engine yang popular saat ini. Disamping itu, Wordpress dapat diperoleh seara gratis dan terbuka (open source), sehingga pengembang dapat melihat dan memperoleh kode secara bebas, dan melakukan modifikasi sesuai keinginan.

Simplest Gallery digunakan untuk memberikan efek pada saat galeri dibuka. Simplest Gallery merupakan plugin paling sederhana untuk mengintegrasikan WordPress dengan Galeri Foto ke halaman website dengan efek visual yang bagus. Pdf Light Viewer Plugin digunakan untuk menampilkan file TA mahasiswa dalalm format pdf. Plugin ini memberikan fasilitas dan kemampuan untuk menanamkan file PDF ke situs Wordpress.

\section{HASIL DAN PEMBAHASAN}

Setelah melakukan proses perancangan dan implementasi, berikut hasil implementasi sistem. Terdapat beberapa bagian dalam repository TA ini. Pada sisi admin terdapat fitur login sebagai admin, input data file dan menu CRUD untuk mengelola data input. Gambar 3 menunjukkan halaman untuk melakukan input data TA mahasiswa, berupa judul TA, nama penulis, tahun lulus, nama pembimbing dan abstrak dan file TA dalam format pdf.

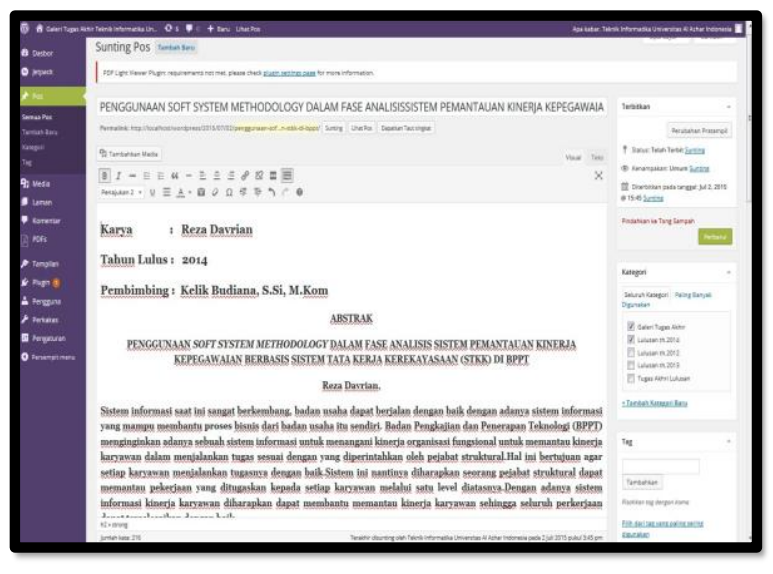

Gambar 3. Input Data TA

Pada sisi user, terdapat fitur untuk melihat Poster, mencari TA berdasarkan kategori, dan melihat file TA dalam format pdf.

Pada halaman awal (home) ditampilkan poster TA mahasiswa yang diurutkan berdasarkan tahun kelulusan mahasiswa. Untuk melihat isi TA mahasiswa yang diinginkan user dapat memilih poster yang sesuai. Gambar 4 menunjukkan halaman awal dari Sistem Repository Portofolio TA Mahasiswa. 


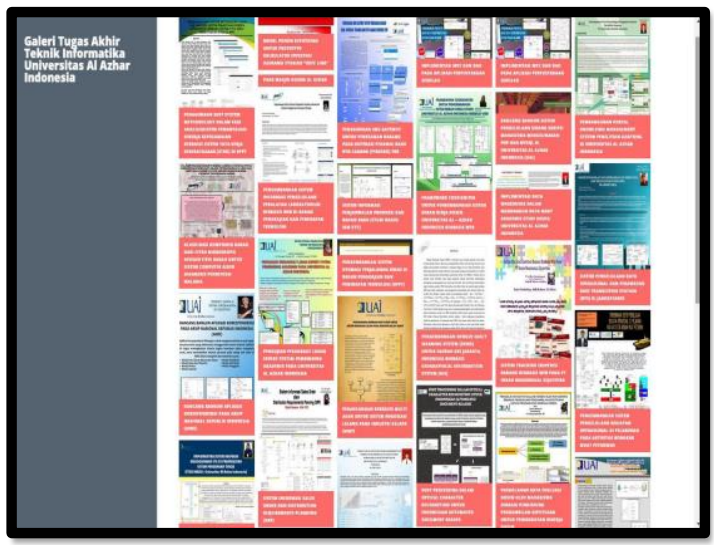

Gambar 4. Tampilan Halaman Home

Setelah memilih poster yang sesuai, user akan diarahkan pada halaman yang berisi abstrak TA dilengkapi dengan data-data penulis. Untuk menuju ke halaman ini, user juga dapat langsung memlih menu Gallery yang disediakan. User juga dapat melakukan pencarian TA dengan menggunakan fitur search yang disediakan di bagian kanan atas sistem.

User juga dapat melihat daftar TA yang terdapat di dalam repository melalui fitur kategori. Kategori yang disediakan dalam repository ini adalah kategori TA berdasarkan tahun kelulusan mahasiswa penulis TA. Gambar 5 menunjukkan tampilan halaman abstrak TA yang telah dipilih user.

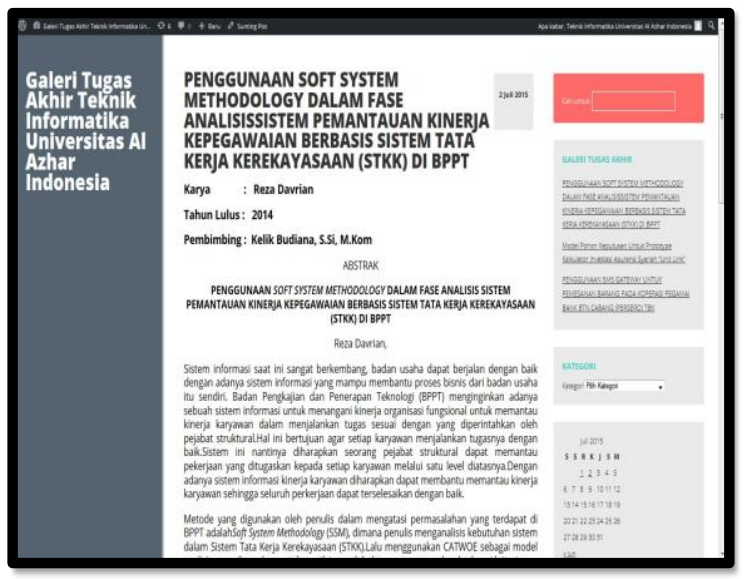

Gambar 5. Tampilan Abstrak TA

Selain melihat abstrak TA, user juga dapat melihat isi dari TA, yaitu BAB I dan screen capture dari aplikasi atau hasil penelitian yang dilakukan. File yang ditampilkan dalam format pdf menggunakan image slide. Tampilan file pdf TA dapat dilihat pada Gambar 6 berikut.

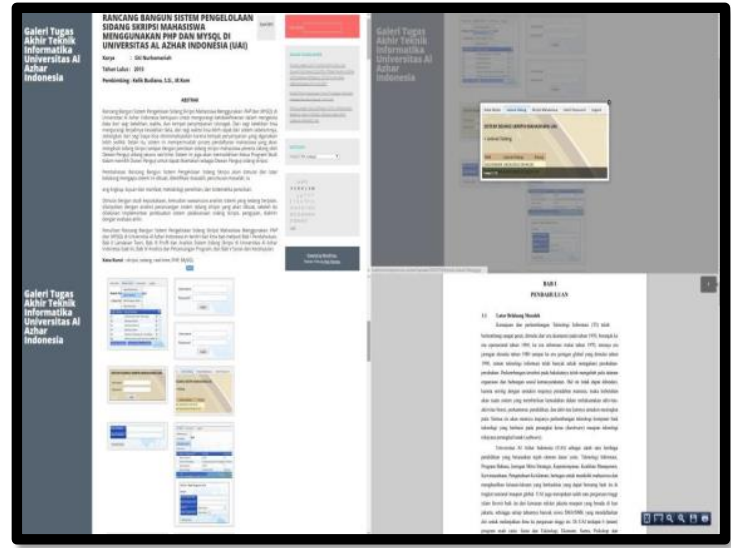

Gambar 6. Tampilan Pdf TA yang dipilih User

Setelah melakukan tahapan implementasi, dilanjutkan dengan pengujian sistem. Pengujian dilakukan dengan menguji semua fitur yang disediakan dapat berfungsi dengan tepat. Disamping itu dilakukan juga pengujian kepada Prodi Teknik Informatika Kaprodi dan Dosen serta staf laboratorium yang nantinya akan menjadi admin sistem repository. Berdasarkan hasil pengujian, Prodi Teknik Informatika memberikan tanggapan positif dan puas terhadap sistem repository yang telah dibuat.

\section{KESIMPULAN}

Repository potofolio TA mahasiswa Teknik Informatika telah berhasil dibuat menggunakan Web Engine Wordpress. Sistem Repository yang dibuat dilengkapi dengan fitur- fitur yang memberikan kemudahan kepada user dalam mencari informasi mengenai TA mahasiswa. Sistem repository ini, membantu dan memudahkan Prodi Teknik Informatika dalam menyimpan dan mencari informasi TA mahasiswa.

Dengan adanya sistem repository berbasis web ini, diharapkan sivitas akademika Prodi Teknik Informatika dapat mengakses informasi dan mencari referensi TA yang telah dilakukan oleh mahasiswa Teknik Informatika.

\section{UCAPAN TERIMA KASIH}

Ucapan terimakasih kami sampaikan kepada $1 \mathrm{p} 2 \mathrm{~m}$ uai atas kesempatan yang diberikan untuk publikasi di jurnal UAI. 


\section{DAFTAR PUSTAKA}

[1] F. Kartika, Samadri, Y.Anton. Sistem Informasi Perpustakaan Berbasis Web dengan PHP dan My SQL. Telkomnika Vol 6. 2008.

http://telkomnika.ee.uad.ac.id/n9/files/Vo l.6No.2Agt08/6.2.8.08.05.pdf. (Diakses pada Oktober 2016)

[2] Minarni, S.Fazril Hadi. Sistem Informasi Perpustakaan Berbasis Web pada Politeknik Kesehatan Padang. Jurnal teknologi informasi \& pendidikan ISSN : 2086 - 4981 . vol. 3. no. 1. maret 2011. http://jurnal-tip.net/jurnal-

resourcelfile/10-Vol3No1Maret2011-

Minarni-Fazril\%20Hadi\%20Saputra.pdf.

(Diakses pada September 2016)

[3] Guidelines for the creation of institutional repositories at universities and higher education organisations / Alfa Network Babel Library. Valparaiso: Columbus : Europe Aid Co-Operation Office : Babel Library, 2007. https://www.jiscmail.ac.uk/cgibin/webadmin? $A 3=$ ind $0709 \& L=j i s c-$ repositories $\& P=287413 \& E=2 \& B=$ $\% 3 D$ NextPart 001 01C7F6D4.A1B06 $912 \& N=$ Guidelines $+I R+$ english.pdf\& $T=$ application\%2Fpdf. (Diakses pada September 2016)

[4] Collins,A, 1992. Potofolio for Science Education: Issues in Purpose, Structure, and Authenticity. Science Education.76(4): 451-463.

[5] Paulson, F.L and Meyer, C.A., 1991. What Make Portofolio? Eight Thoughtfulo Guidelines Will Help Educations Encourage Self Directed Learning: Educational Leardership.

[6] Tutorials Point. Wordpress Tutorials Point,: Simply Easy Learning. 2015. http://www.tutorialspoint.com/wordpress lwordpress_tutorial.pdf. (Diakses pada September 2016) 